\title{
428. Stellenwert der Dopplersonographie bei hochgradigen Stenosen der A. carotis interna
}

\author{
F. Utz, H. Fürst und H. M. Becker \\ Chirurgische Klinik und Poliklinik der Universität München (Direktor: Prof. Dr. G. Heberer), \\ Klinikum Großhadern, Marchioninistraße 15, D-8000 München 70
}

\section{Noninvasive Diagnosis of Severe Extracranial Stenoses of the Intemal Carotid Artery: Validity of Doppler Ultrasonography}

\begin{abstract}
Summary. During the last 2 years 1,035 patients have been subjected to directional continuous-wave Doppler ultrasonography. In all 248 severe stenoses of the internal carotid arteries were identified. Of these, 89 were checked by angiography and in 85 cases the diagnosis made with Doppler ultrasonography was confirmed. Another 106 stenoses were operated upon without preoperative Doppler diagnosis. Thus the reliability of the method proved to be $97 \%$. It is concluded that patients with high angiographic risk may be safely subjected to surgery on the basis of Doppler ultrasonography alone.
\end{abstract}

Key words: Doppler ultrasonography - Internal carotid artery stenosis.

Zusammenfassung. In den Jahren 1981 und 1982 wurden 1035 Patienten mit Hilfe des direktionellen Dopplerverfahrens mit kontinuierlicher Schallaussendung untersucht. 248 hochgradige und filiforme Carotis interna-Stenosen wurden festgestellt. Davon wurden 89 Stenosen angiographisch kontrolliert. In 85 Fällen bestätigte sich die dopplersonographische Diagnose. 106 weitere Stenosen wurden ohne präoperatives Angiogramm operiert. In 105 Fällen bestätigte sich intraoperativ die dopplersonographische Diagnose. Die Treffsicherheit von $97 \%$ berechtigt dazu, Patienten mit erhöhtem angiographischen Risiko ohne präoperatives Angiogramm zu operieren.

Schlüsselwörter: Dopplersonographie - Carotis interna-Stenose.

\section{Transplantataustausch in einer Sitzung als operative Methode bei Mehrfach-Nierentransplantationen}

\author{
W. Land und W.-D. Illner \\ Transplantationszentrum (Leiter: Prof. Dr. W. Land) der Chirurgischen Klinik und Poliklinik \\ (Dir.: Prof. Dr. G. Heberer) der Universität München, Klinikum Großhadern, \\ Marchioninistraße 15, D-8000 München 70
}

\section{Transplant Exchange as an Operative Method in Cases of Renal Retransplantation in Man}

\begin{abstract}
Summary. In certain cases it seems reasonable to remove a nonfunctioning transplant and then perform ipsilateral retransplantation in the same session. This has so far been done in five cases. The surgical technique used consisted of (1) removal of the previous transplant; (2) transplantation of the "new" allograft at the site of the previous end-to-side anastomosis, leaving the original arterial and venous patches of the first graft to form the new end-to-side anastomosis between the renal and external iliac vessels. Neither perioperative nor postoperative complications have been observed so far.
\end{abstract}

Key words: Renal retransplantation - New techniques.

Zusammenfassung. In bestimmten Fällen erscheint es sinnvoll in einer Sitzung mit der Transplantatenentfernung die Retransplantation auf der ipsilateralen Seite vorzunehmen. Bei 5 Patienten wurde diese Methode bisher durchgeführt. Die Operationstechnik bestand in (I) der Entfernung des ehemaligen Transplantates, (II) in der Retransplantation, wobei die ehemaligen Anastomosenstellen unter Belassung der ,,alten " arteriellen und venösen Gefäßpatche im Bereich der externen Iliacalgefäße zur neuerlichen End-zu-Seit-Anastomose benutzt wurden (,patch-to-patch"-Technik). Intra- bzw. postoperative Komplikationen wurden bei dieser operativen Methode bisher nicht beobachtet.

Schliusselwörter: Nieren-Mehrfachtransplantation - Operationstechnik. 